\title{
Competition between Rhizobium trifolii Strains for Nodulation, during Growth in a Fermenter, and in Soil-based Inoculants, Studied by ELISA
}

\author{
By ANNA M. MÅRTENSSON* AND JAN-GUNNAR GUSTAFSSON† \\ Department of Microbiology, Swedish University of Agricultural Sciences, Box 7025 , \\ S-75007 Uppsala, Sweden
}

(Received 8 March 1985; revised 21 June 1985)

\begin{abstract}
An improved ELISA technique using a new type of enzyme-conjugate - the antibody being linked to $\beta$-galactosidase by using a heterobifunctional reagent, $N$-succinimidyl-3-(2pyridyldithio)propionate (SPDP), containing two reactive groups directed towards different functional sites - has been further improved by fine purification of the antibodies. The ELISA was applied in studies of competition among strains of Rhizobium trifolii in three environments : a rhizosphere, a liquid medium and in soil. The strain origin of nodules formed by strain mixtures of different relative composition was investigated, including a study of double strain occupancy. Strain 7612 was found to compete successfully with strain 285 for nodulation. No double strain occupancy occurred. Strain 7612 also competed successfully with strain 285 in soil, but strain 285 dominated when grown together with strain 7612 in a liquid medium in a fermenter.
\end{abstract}

\section{INTRODUCTION}

Production of Rhizobium inoculants for agricultural purposes has a long history, especially in Sweden, where it dates back to the early 1900s (Barthel \& Rhodin, 1914). Introduction of inoculants to fields devoid of native Rhizobium may produce a substantial increase in the yield of inoculated legume crops (Nutman, 1976). Sometimes, however, the inoculation fails and no beneficial effects are noted. This lack of response to inoculation may be explained by several factors. Unfavourable conditions in the field, e.g. high/low pH (Holding \& King, 1963), high/low nutrient status (Barber, 1980), or desiccation (Bushby \& Marshall, 1977), are some of the soil physical and chemical factors that may strongly influence the survival of the inoculated strains.

Biological factors that may influence the success of inoculation include root exudates - those of legume as well as non-legume origin influence the chemotaxis of Rhizobium (Gaworzewska \& Carlile, 1982) - and nematodes grazing on Rhizobium, which are known to influence the population density (Ramirez \& Alexander, 1980). However, the possible influence of competition between strains of Rhizobium remains unclear. At the field site, well-adapted 'wild' strains, with low nitrogen-fixing ability and/or high nodulation ability, may dominate the highly efficient, laboratory-tested inoculated strains. A reliable method of studying these phenomena, based on immunological differences between bacterial strains, has been presented (Mårtensson et al., 1984). In this work, the technique has been further improved and applied to study competition between Rhizobium strains in forming root nodules, during growth in a fermenter, and during growth in soil serving as a carrier for a commercial inoculant. An investigation of double strain occupancy of nodules was also included.

† Present address: Pharmacia AB Biotechnology, S-751 82 Uppsala, Sweden. 


\section{METHODS}

Immunization. Immunization procedures for production of antibodies were as previously described (Mårtensson et al., 1984), except that intact cells of Rhizobium trifolii, rather than $R$. meliloti, were used.

Antibody purification. Serum samples, stored at $-70^{\circ} \mathrm{C}$, were thawed for $2 \mathrm{~h}$ at $-20^{\circ} \mathrm{C}$ and for $4 \mathrm{~h}$ at $5{ }^{\circ} \mathrm{C}$. The serum was then centrifuged $(20000 \mathrm{~g})$ for $25 \mathrm{~min}$ at $5^{\circ} \mathrm{C}$ and the supernatant diluted with 3 vols $0.02 \mathrm{M}$-sodium phosphate $/ 0.02 \mathrm{M}-\mathrm{NaCl}$ buffer, $\mathrm{pH} 6 \cdot 7$. Then $50 \%(\mathrm{w} / \mathrm{w}$ ) polyethylene glycol, mol. wt 6000 , in distilled water, was added dropwise, with gentle stirring, to give a concentration of $15 \%(w / w)$. The solution was allowed to stand for $16 \mathrm{~h}$ at $5{ }^{\circ} \mathrm{C}$, and then centrifuged $(3000 \mathrm{~g})$ at room temperature for $20 \mathrm{~min}$. The precipitate was dissolved in a volume of $0.02 \mathrm{M}$-potassium phosphate $/ 0.02 \mathrm{M}-\mathrm{KCl}$ buffer, $\mathrm{pH} 6.7$, equal to $2 / 3$ of the original serum volume. The solution was then applied to a Cibachron Blue F3G-A-Sepharose CL-6B (Pharmacia) column $\left(V_{\mathrm{t}}=10 \mathrm{ml}\right)$ equilibrated with $0.02 \mathrm{M}$-potassium phosphate $/ 0.02 \mathrm{M}-\mathrm{KCl}$ buffer, $\mathrm{pH} 6.7$. The activities of the eluted fractions were investigated by immunoelectrophoresis. Fractions showing immunoprecipitate lines were combined and diluted with 6 vols $0.02 \mathrm{M}$-sodium phosphate $/ 0.02 \mathrm{M}-\mathrm{NaCl}, \mathrm{pH} 6.7$, and chromatographed on a DEAE-Sephadex A-50 (Pharmacia) column $\left(V_{1}=15 \mathrm{ml}\right)$ equilibrated with $0.02 \mathrm{M}$-sodium phosphate $/ 0.02 \mathrm{M}-\mathrm{NaCl}, \mathrm{pH} 6 \cdot 7$. Bound material was eluted with a linear gradient $(0 \cdot 02-0 \cdot 2 \mathrm{M})$ of $\mathrm{NaCl}$ in equilibration buffer. The eluted fractions were investigated by immunoelectrophoresis. Finally, fractions containing active $\operatorname{IgG}$ were concentrated to a final concentration of $15 \mathrm{mg}$ active $\mathrm{IgG} \mathrm{m} \mathrm{m}^{-1}$ by ultrafiltration using an Amicon ultrafilter cell equipped with a PM30 membrane, and divided into samples of $2.5 \mathrm{mg} \mathrm{IgG}$, which were stored at $-70^{\circ} \mathrm{C}$ prior to enzyme conjugation.

Immunoelectrophoresis. Immunoelectrophoresis of eluates was done by using gel slabs $(80 \times 80 \mathrm{~mm})$ covered with $10 \mathrm{ml} 1 \%$ Agarose B (Pharmacia) in $0.09 \mathrm{M}$-5,5-diethylbarbituric acid $/ 0 \cdot 18 \mathrm{M}$-Tris/5 mM-calcium lactate, $\mathrm{pH} 8 \cdot 6, I=0 \cdot 050$. The slabs were prepared by cutting two rows ( $3 \mathrm{~mm}$ apart) of seven holes each in the agar; each hole had a volume of $5 \mu \mathrm{l}$. Samples of antigen - the supernatant of a bacterial suspension $\left(10^{10} \mathrm{cells}^{-1}\right)$ heated at $60{ }^{\circ} \mathrm{C}$ for $20 \mathrm{~min}$ and centrifuged $(2000 \mathrm{~g})$ for $15 \mathrm{~min}$ - were placed in the holes facing the anode and the eluates from the chromatography were placed opposite. Electrophoresis was performed at $300 \mathrm{~V}, 100 \mathrm{~mA}$ for $10 \mathrm{~min}$, using a flat-bed electrophoresis apparatus with very efficient cooling (Pharmacia). Then the slabs were left in $0.85 \% \mathrm{NaCl}$ for $2-4 \mathrm{~h}$, stained in $0.2 \%$ Coomassie Blue R-250 in methanol/acetic acid/distilled water $(3: 1: 6$, by vol.) for $10 \mathrm{~min}$, and destained in methanol/acetic acid/distilled water $(3: 1: 6$, by vol.) for some hours.

Preparation of enzyme-conjugates. The preparation of enzyme-conjugates using a hetero-bifunctional reagent, $\mathrm{N}$ succinimidyl-3-(2-pyridyldithio)propionate (SPDP), was done as reported earlier (Mårtensson et al., 1984). Three enzyme-conjugates, against $R$. trifolii strains 285,828 and 7612 , respectively, were prepared.

Preparation of ELISA samples. Test samples, normally consisting of bacterial cells, were centrifuged $(2000 \mathrm{~g})$ at room temperature for $10 \mathrm{~min}$. The bacterial cells were then resuspended in $0.02 \mathrm{M}$-sodium phosphate $/ 0.02 \mathrm{M}$ $\mathrm{NaCl} / 2 \mathrm{~mm}-\mathrm{MgCl}_{2} / 0 \cdot 1 \%$ Tween $20, \mathrm{pH} 7 \cdot 1$. The washing procedure was repeated three times.

ELISA test procedure. Polystyrene test-tubes (vol. $4 \mathrm{ml}$ ) were washed once with $3.5 \mathrm{ml}$ washing buffer consisting of $0.9 \% \mathrm{NaCl} / 0.02 \mathrm{M}$-sodium phosphate $/ 0.25 \%$ Tween $20 / 2 \mathrm{mM}-\mathrm{MgCl}_{2}, \mathrm{pH} 7 \cdot 1$. Test samples, normally $200 \mu \mathrm{l}$, were added to each test-tube. Then $100 \mu \mathrm{l}$ enzyme-conjugate, diluted in buffer $[0 \cdot 9 \% \mathrm{NaCl} / 0 \cdot 02 \mathrm{M}$-sodium phosphate $/ 0.3 \%$ dextran T40 (Pharmacia) $/ 0.5 \%$ Tween $20 / 2 \mathrm{mM}-\mathrm{MgCl}_{2} / 0 \cdot 2 \%$ human serum albumin (Sigma), pH 7.1] to give $2 \mu \mathrm{g} \mathrm{IgG} \mathrm{m} \mathrm{m}^{-1}$, was added and incubated for $4 \mathrm{~h}$, shaken at $225 \mathrm{r.p.m}$. at room temperature. Washing buffer $(2 \mathrm{ml})$ was added, and the mixture was allowed to stand for $10 \mathrm{~min}$, and then centrifuged $(2000 \mathrm{~g})$ for $10 \mathrm{~min}$ at room temperature, after which $1.7 \mathrm{ml}$ was withdrawn. This procedure was repeated three times. Then $200 \mu \mathrm{l}$ substrate, consisting of $o$-nitrophenyl $\beta$-D-galactopyranoside (Sigma, $3.5 \mathrm{mg} \mathrm{ml}^{-1}$ in $0.2 \mathrm{M}$-sodium phosphate $/ 2 \mathrm{mM}-\mathrm{MgCl}_{2} / 20 \%, \mathrm{v} / \mathrm{v}$, methanol, $\mathrm{pH} \mathrm{7.1)}$ was added and the test-tubes were incubated for $1 \mathrm{~h}$ at room temperature. The enzyme reaction was stopped by adding $0.7 \mathrm{ml} 0.7 \mathrm{M}-\mathrm{Na}_{2} \mathrm{CO}_{3}$. The test-tubes were finally centrifuged $(2000 \mathrm{~g})$ at room temperature for $10 \mathrm{~min}$ and the absorbance $\left(A_{418}\right)$ of the supernatant was recorded by using a Beckman spectrophotometer equipped with a quartz micro-cuvette of $1 \mathrm{~cm}$ light path.

Bacterial strains. R. trifolii strains 285,828 and 7612, obtained from the Legume Laboratory, Swedish University of Agricultural Sciences, were used; they were grown and maintained on BIII-medium (Bishop et al., 1976).

Reproducibility of ELISA. Strains 285 and 7612 were grown on BIII-medium in shaken flasks, $28^{\circ} \mathrm{C}$, to early stationary phase. The cells were harvested and routinely washed as described above, prior to ELISA. The cell concentration of each strain was adjusted to $10^{4}$ cells $\mathrm{ml}^{-1}$ by adding $0.02 \mathrm{M}$-sodium phosphate/0.02 $\mathrm{M}$ $\mathrm{NaCl} / 2 \mathrm{~mm}-\mathrm{MgCl}_{2} / 0 \cdot 1 \%$ Tween 20 buffer, $\mathrm{pH} 7 \cdot 1$, if necessary. The strains were mixed in the following proportions: $0: 1,1: 1$ and $1: 0$. The day-to-day reproducibility of ELISA was investigated by repeating the experiment on three subsequent days, each with new batches of bacteria.

ELISA of strain mixtures. The ELISA absorbance values were recorded using several combinations of mixtures of strains 828 and 7612 , prepared as described above.

Double strain occupancy of nodules studied by ELISA. Four-to five-day-old sterile red clover (Trifolium pratense) seedlings, cv. Britta, planted on agar slopes in test-tubes (Vincent, 1970), were inoculated with mixtures of strains 828 and 7612 . After 6 weeks' growth, each nodule was carefully cut from its root system, momentarily rinsed in $70 \%(\mathrm{v} / \mathrm{v})$ ethanol followed by running tap water and macerated with a glass rod in $200 \mu \mathrm{l}$ ELISA test-tube 
Table 1. Reproducibility of ELISA

An enzyme-conjugate against $R$. trifolii 285 , cell concentration $10^{4}$ cells $\mathrm{ml}^{-1}$, was used for three replicates of each sample. The control was cell washing buffer.

\begin{tabular}{ccccc} 
Strain mixture & \multicolumn{2}{c}{$A_{+18}(\mathrm{SD}$ in parentheses) } & \\
\cline { 2 - 4 } $285: 7612$ & Expt 1 & Expt 2 & $P$ value* \\
$1: 0$ & $0.793(0.153)$ & $0.714(0.061)$ & $0.772(0.087)$ & $>0.05$ \\
$1: 1$ & $0.558(0.014)$ & $0.527(0.115)$ & $0.605(0.065)$ & $>0.05$ \\
$0: 1$ & $0.248(0.023)$ & $0.232(0.102)$ & $0.248(0.014)$ & $>0.05$ \\
Control & $0.231(0.004)$ & $0.215(0.010)$ & $0.208(0.017)$ & $>0.05$
\end{tabular}

* For each strain mixture, the results of the three experiments were compared with each other by the ANOVA test (Wonnacott \& Wonnacott, 1972). Since the $P$-values exceeded 0.05 in all cases, the observed differences in means can be attributed to chance fluctuations.

washing buffer. Each nodule suspension was divided into two test-tubes and tested separately with enzymeconjugates against strains 828 and 7612 .

Competition between rhizobial strains. (i) In root nodules. Four- to five-day-old sterile red clover seedlings, cv. Britta, planted as described above, were inoculated with mixtures of strains 285 and 7612 . After 6 weeks' growth, the nodules were prepared for ELISA by washing and maceration as described above.

(ii) During growth in a fermenter. Suspensions of strains 285 and $7612\left(200 \mathrm{ml}, \mathrm{OD}_{5+0}=0 \cdot 1\right)$ were used to inoculate a 4-litre fermenter, containing 3.5 litres BIII-medium, operated at $28{ }^{\circ} \mathrm{C}$ with the pH automatically adjusted to 7.4 with $40 \%(\mathrm{w} / \mathrm{v}) \mathrm{KOH}$. The $\mathrm{OD}_{540}$ of the cell suspension was recorded and cell samples were withdrawn at intervals for ELISA; all these samples were adjusted to the same cell density.

(iii) In soil-based commercial inoculants. Autoclaved inoculant tins filled with soil (wet weight $125 \mathrm{~g}, \mathrm{pH} 7$ ), intended for routine commercial production of Rhizobium inocula at the Legume Laboratory, Swedish University of Agricultural Sciences (Ljunggren \& Mårtensson, 1984), were inoculated with mixtures of strains 285 and 7612. After 2 weeks' incubation at room temperature, $1 \mathrm{~g}$ (wet weight) soil was withdrawn and mixed with $10 \mathrm{ml} 0 \cdot 02 \mathrm{M}$ sodium phosphate $/ 0 \cdot 02 \mathrm{M}-\mathrm{NaCl} / 2 \mathrm{mM}-\mathrm{MgCl}_{2} / 0 \cdot 1 \%$ Tween 20 buffer, $\mathrm{pH} 7 \cdot 1$, in a whirlimixer for $1 \mathrm{~min}$. The soil suspension was then put aside for $10 \mathrm{~min}$ before being decanted and filtered through filter paper (Munktell no. 3). ELISA was performed on $200 \mu$ l of the filtrate.

\section{RESULTS AND DISCUSSION}

A drawback in studying bacterial strains by serological techniques is that the antibodies used may be highly cross-reactive, and thus may fail to distinguish between strains. However, serological methods have many advantages over other identification techniques. For instance, uncertainty about the stability of antibiotic resistance markers (Stein et al., 1982), and fluctuations in plasmid composition (Beynon et al., 1980) and in enzyme and protein patterns (Mytton et al., 1978; Roberts et al., 1980) make these other techniques questionable. The crossreactivity, when it occurs, is probably caused by inadequate purification of the antibodies. In this study we evaluated a purification system, including gentle precipitation of the $\operatorname{IgG}$ by polyethylene glycol, followed by affinity chromatography to remove impurities such as ferritin. The active eluates, which were eluted after $1.5 V_{t}$, were combined and placed on an anionexchange column and the active IgG was then eluted at $0.12 \mathrm{M}-\mathrm{NaCl}$ by a $\mathrm{NaCl}$ gradient. This technique enabled us to obtain highly specific and reactive IgG. A further advantage is that the purification steps are easily followed by a developed immunoelectrophoresis method. The derived antibodies were then linked to $\beta$-galactosidase by a hetero-bifunctional reagent, thus avoiding enzyme-enzyme and/or antibody-antibody linkages.

In evaluating different methods, reproducibility is very important. The ELISA approach used was studied for reproducibility on three separate occasions, and the results showed that the reproducibility was good (Table 1 ). To assess the applicability of the ELISA to quantitative studies of unknown cell samples, we investigated whether an increase in the proportion of a strain within a mixture caused an increase in ELISA absorbance values. As shown in Fig. 1, the ELISA absorbance values of a mixture of two $R$. trifolii strains increased linearly with increases in the number of bacteria of the strain which reacted with the enzyme-conjugate used. We conclude that the ELISA method is a useful quantitative assay. 


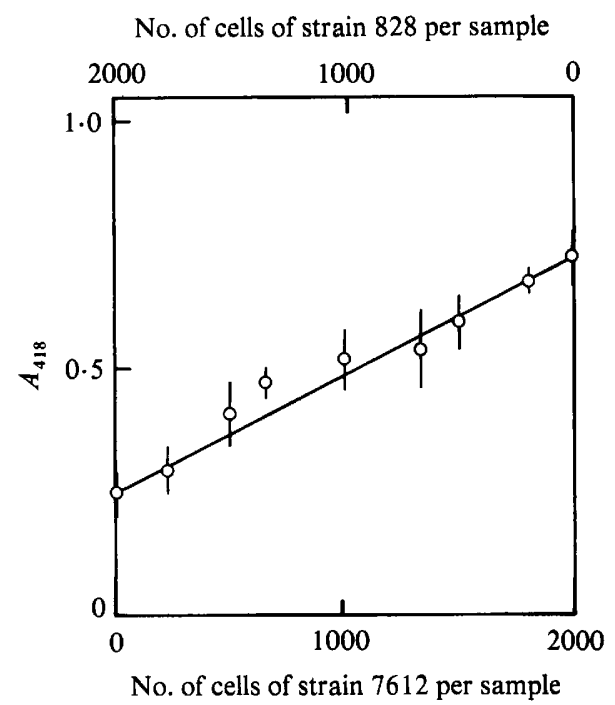

Fig. 1. ELISA of mixtures of $R$. trifolii strains 828 and 7612, using enzyme-conjugate against strain 7612. The bars indicate SD $(n=4)$.

Table 2. Tests by ELISA for the occurrence of double strain occupancy of red clover root nodules by $R$. trifolii strains

$\begin{array}{ccc}\begin{array}{c}\text { Nodule } \\ \text { no. }\end{array} & \begin{array}{c}\text { Enzyme- } \\ \text { conjugate } \\ \text { vs. } 828\end{array} & \begin{array}{c}\text { Enzyme- } \\ \text { conjugate } \\ \text { vs. } 7612\end{array} \\ 1 & 0.325 & 0.137 \\ 2 & 0.285 & 0.127 \\ 3 & 0.419 & 0.090 \\ 4 & 0.362 & 0.140 \\ 5 & 0.171 & 0.355 \\ 6 & 0.115 & 0.332 \\ 7 & 0.082 & 0.316 \\ 8 & 0.138 & 0.290\end{array}$

Does the nodule show a significant $(P<0.05)$ relationship

\begin{tabular}{|c|c|c|c|}
\hline \multicolumn{2}{|c|}{ Enzyme-conjugate vs. $828^{*}$} & \multicolumn{2}{|c|}{ Enzyme-conjugate vs. $7612 \dagger$} \\
\hline Strain 828 & Strain 7612 & Strain 828 & Strain 7612 \\
\hline yes & no & yes & no \\
\hline yes & no & yes & no \\
\hline yes & no & yes & no \\
\hline yes & no & yes & no \\
\hline no & yes & no & yes \\
\hline no & yes & no & yes \\
\hline no & yes & no & yes \\
\hline no & yes & no & yes \\
\hline
\end{tabular}

* $A_{418}$ with strain 828: $0 \cdot 358$ (SD 0.0778, $n=10$ ). $A_{418}$ with strain 7612:0.171 (SD 0.0438, $n=10$ ).

$\dagger A_{418}$ with strain 828:0.119 (SD 0.0378, $\left.n=10\right)$. $A_{418}$ with strain 7612:0.366 (SD 0.0931, $\left.n=10\right)$.

Table 3. Strain origin of red clover nodules inoculated with mixtures of $R$. trifolii strains, studied by ELISA

Each nodule was tested with enzyme-conjugate against strain 285 and against strain 7612 , and classified as the respective strain at the $1 \%$ significance level.

$\begin{array}{cc}\begin{array}{c}\text { Inoculum } \\ \text { strain mixture } \\ 285: 7612\end{array} & \begin{array}{c}\text { No. of nodules } \\ \text { of strain } 285\end{array} \\ 100: 0 & 7 \\ 90: 10 & 3 \\ 75: 25 & 1 \\ 67: 33 & 0 \\ 50: 50 & 0 \\ 33: 67 & 0 \\ 25: 75 & 0 \\ 10: 90 & 0 \\ 0: 100 & 0\end{array}$

No. of nodules
of strain 7612
0
4
7
10
8
7
8
6
8

No. of nodules tested

* One nodule could not be identified. 
Percentage of strain 285 at inoculation

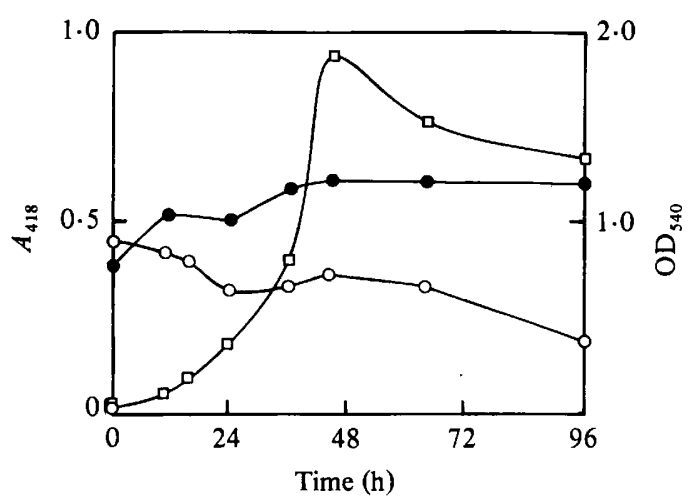

Fig. 2

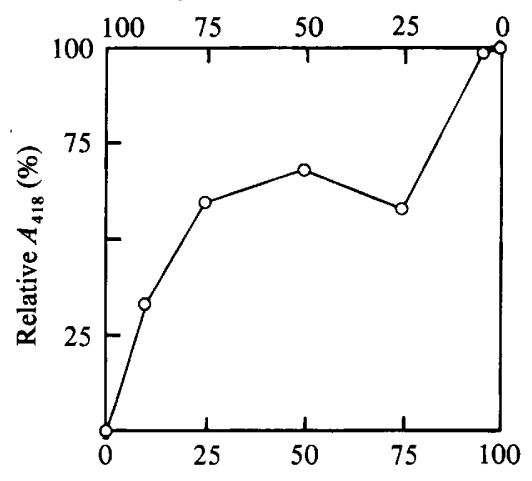

Percentage of strain 7612 at inoculation

Fig. 3

Fig. 2. Numbers of bacterial cells in a mixed culture of $R$. trifolii strains 285 and 7612 during growth in a fermenter, determined by ELISA using enzyme-conjugate against the respective strains. The cell concentration of each sample for ELISA was adjusted to $10^{4}$ cells $\mathrm{ml}^{-1}$. The results are means of three replicates. $\bigcirc, A_{418}$ representing the amount of strain $7612 ; 0, A_{418}$ representing the amount of strain 285: $\square, \mathrm{OD}_{540}$ representing the total amount of cells of the mixed population, determined by direct spectrophotometric measurement of cell suspensions.

Fig. 3. Occurrence of $R$. trifolii strains 285 and 7612 in a commercial soil inoculant that had been inoculated with different strain mixtures 2 weeks previously, determined by ELISA using enzymeconjugate against strain 7612 . The $A_{+18}$ with strain $7612(0.604)$ was taken as $100 \%$, and the $A_{418}$ with strain $285(0.286)$ as $0 \%$. The results are means of three replicates.

We examined whether double strain occupancy of nodules occurred by dividing nodule suspensions into two parts, and testing these separately with enzyme-conjugates against each of the inoculated strains. The results in Table 2 show that double strain occupancy did not occur. Low frequencies of double infections were reported by Brockwell et al. (1976) using antigenic and streptomycin resistance markers for Rhizobium strains in clover, and by Diatloff \& Brockwell (1976) using antigenic markers for strains in soyabeans. In contrast, Johnston \& Beringer (1975), using genetic markers, reported that mixed strain occupancy of nodules could exceed $20 \%$ of the pea nodules that they investigated. The present investigation has the advantage that by using enzyme-conjugates against both of the inoculated strains to investigate single nodules, we were able to double check our results. The ELISA approach also avoids the time- and space-consuming procedure conventionally used to investigate double strain infection, which involves the cultivation of nodule suspensions on agar plates. On these plates, a strain which dominates in the nodule may be outcompeted by another when growing on agar, thus giving rise to incorrect conclusions.

Having concluded that double strain occupancy does not occur, we investigated competition for nodule sites by two strains of $R$. trifolii (Table 3). Strain 7612 successfully competed with strain 285 in nodulation: even if strain 285 formed $90 \%$ of the inoculation mixture, it was recovered in only three out of eight nodules. However, during growth in liquid medium in a fermenter, the strains responded in the opposite way, and strain 285 finally dominated (Fig. 2). The possibility that the derived ELISA values might differ during growth in the fermenter, due to changes in antigenic properties, was excluded by a control experiment in which strain 7612 was grown in the fermenter alone, and tested by ELISA occasionally during growth. It did not show any differences in ELISA absorbance values during growth (the cell density of the test samples was kept constant). This contrasts with results obtained by Hrabak et al. (1981), who studied the antigenic properties of the root-hair linking sites of the cell wall, but these are probably not the antigenic sites of the cell wall used by us. We also investigated strain competition in soil, using commercial inoculant tins (see Methods). The results in Fig. 3 show 
that as in the nodulation tests, strain 7612 dominated over strain 285 , even when strain 285 constituted $90 \%$ of the initial inoculation mixture. The use of strain mixtures in commercial inoculant production, as reported by Ljunggren \& Mårtensson (1984), is therefore questionable, since the present investigation demonstrates that one strain may dominate the population.

In conclusion, by means of the ELISA approach we were able to demonstrate the occurrence of competition between strains of $R$. trifolii. Strain 7612 was a successful competitor for nodulation and for growth in soil, whereas in a liquid medium strain 285 dominated. The underlying reasons for these differences in competitive ability remain to be answered.

This work was partly supported by a grant from the Swedish Council for Forestry and Agricultural Research (Anna Mårtensson).

\section{REFERENCES}

BARBER, L. E. (1980). Enumeration, effectiveness and $\mathrm{pH}$ resistance of Rhizobium meliloti populations in Oregon soils. Soil Science Society of America Journal 44, 537-539.

BARTHel, C. \& RHOdin, S. (1914). Experiments with cultures of leguminous bacteria for blue lupin and blue lucerne. (In Swedish) Meddelande no. 95, Centralanstalten för försöksväsendet på jordbruksområdet, Bakteriologiska laboratoriet no. 10. Stockholm: Häggström.

Bishop, P. E., Guevara, J. G., Engelke, J. A. \& Evans, H. J. (1976). Relation between glutamine synthetase and nitrogenase activities in the symbiotic association between Rhizobium japonicum and Glycine max. Plant Physiology 57, 542-546.

Beynon, J. L., Beringer, J. E. \& Johnston, A. W. B. (1980). Plasmids and host-range in Rhizobium leguminosarum and Rhizobium phaseoli. Journal of General Microbiology 120, 421-429.

Brockwell, J., Schwinghamer, E. A. \& Gault, R. R. (1976). Studies of root nodule bacteria introduced into field environments. $V$. A critical examination of the stability of antigenic and streptomycin-resistance markers for identification of strains of Rhizobium trifolii. Soil Biology and Biochemistry 9, 19-24.

Bushby, H. V. A. \& Marshall, K. C. (1977). Some factors affecting the survival of root-nodule bacteria on desiccation. Soil Biology and Biochemistry 9, 143147.

DiatlofF, A. \& BRockwell, J. (1976). Ecological studies of root-nodule bacteria introduced into field environments. 4. Symbiotic properties of Rhizobium japonicum and competitive success in nodulation of two Glycine max cultivars by effective and ineffective strains. Australian Journal of Agriculture and Animal Husbandry 16, 514-521.

Gaworzewska, E. T. \& Carlile, M. J. (1982). Positive chemotaxis of Rhizobium leguminosarum and other bacteria towards root exudates from legumes and other plants. Journal of General Microbiology 128, 1179-1188.

Holding, A. J. \& KING, J. (1963). The effectiveness of indigenous populations of Rhizobium trifolii in relation to soil factors. Plant and Soil 18, 191-198.
Hrabak, E. M., Urbano, M. R. \& Dazzo, F. D. (1981). Growth-phase-dependent immunodeterminants of Rhizobium trifolii which bind trifoliin A, a white clover lectin. Journal of Bacteriology 148, 697711.

Johnston, A. W. B. \& Beringer, J. E. (1975). Identification of Rhizobium strains in pea root nodules using genetic markers. Journal of General Microbiology 87, 343-350.

LjungGren, H. \& MÅrtensson, A. M. (1984). Legume-inoculant production in Sweden. Swedish Journal of Agricultural Research 14, 177-181.

Mytton, L. R., McAdam, N. J. \& Portlock, P. (1978). Enzyme polymorphism as an aid to identification of Rhizobium strains. Soil Biology and Biochemistry 10, 79-80.

Mårtensson, A. M., Gustafsson, J.-G. \& LuungGREN, H. D. (1984). A modified, highly sensitive enzyme-linked immunosorbent assay (ELISA) for Rhizobium meliloti strain identification. Journal of General Microbiology 130, 247-253.

NutMan, P. S. (1976). IBP field experiments on nitrogen fixation by nodulated legumes. In Symbiotic Nitrogen Fixation in Plants (IBP Handhook no. 7), pp. 211-237. Edited by P. S. Nutman. Cambridge: Cambridge University Press.

Ramirez, C. \& Alexander, M. (1980). Evidence suggesting protozoan predation on Rhizobium associated with germinating seeds and in the rhizosphere of beans (Phaseolus vulgaris L.). Applied and Environmental Microbiology 40, 492-499.

Roberts, G. P., LePS, W. T., Silver, L. E. \& Brill, W. J. (1980). Use of two-dimensional polyacrylamide gel electrophoresis to identify and classify Rhizobium strains. Applied and Environmental Microbiology 39, 412-422.

Stein, M., Bromfield, E. S. P. \& Dye, M. (1982). An assessment of a method based on intrinsic antibiotic resistance for identifying Rhizobium strains. Annals of Applied Biology 101, 261-267.

VINCENT, J. M. (1970). A Manual for the Practical Study of the Root Nodule Bacteria (IBP Handbook no. 15). Oxford: Blackwell Scientific Publications.

WonNacotT, T. H. \& WonNacotT, R. J. (1972). Introductory Statistics. New York: John Wiley. 